\title{
Safe Space
}

\author{
Christine Quinan
}

Like many other contributors to this volume, my teaching philosophy is shaped by a queer pedagogical praxis; that is, it is fundamentally structured around an acknowledgment and questioning of privilege, hierarchy, and traditional approaches to learning and teaching alongside an interrogation of what it means to speak and be heard within both educational institutions and queer communities. The classroom is a space of both critical inquiry and emotional involvement, a space that we all negotiate differently depending on learning styles and abilities, levels of comfort in speaking, relationships to English, feelings toward academic "jargon," and opinions on the oft-confining physical classroom, among other factors. Here, the creation of spaces where students can ask critically minded questions and express their opinions on controversial topics becomes essential. In recognizing the classroom as a space of vulnerability, the concept of "safe space" may prove helpful yet also potentially problematic. Because what is safe for some is certainly not for others and because "safety" is a privilege to which not all have access, can safe spaces exist? In negotiating this question, Annette Henry's (1994) words remain prescient: “There is nothing 'safe' about engaging stu-

C. Quinan $(\bowtie)$

Utrecht University, Utrecht, The Netherlands

(C) The Editor(s) (if applicable) and The Author(s) 2016

361

N.M. Rodriguez et al. (eds.), Critical Concepts in Queer Studies

and Education, DOI 10.1057/978-1-137-55425-3_35 
dents in rigorous and critical ways. It seems to me that to be able to speak of safety in the 'belly of the beast' reveals class and race privilege. Only a certain elite has the privilege of cultivating a safe space in mainstream institutions that perpetuate the very inequities which we fight against as feminist educators" (p. 2). What, then, are our responsibilities as queer educators in creating certain types of environments? In queer pedagogy, should we be wary of a discourse of "safety" that may feed into neoliberal focuses on security and surveillance? What tools can we use to challenge this rhetoric while maintaining a focus on the politics of speaking and being heard?

Of course the notion of safety has long been at the heart of feminist and queer activism and scholarship, with first Women's Studies and then lesbian, gay, bisexual, transgender, and queer studies programs being in part born out of a need for safe spaces in heteronormative male-centered academic institutions. But when it comes to the concept of "safe space," where are we now? It often seems that the term has become a catchall for discussing the type of teaching and learning environment we think we should strive for, but it often goes unexplained and sometimes unquestioned; indeed, we may believe that our job as queer educators involves attempting to create such safety and security for students to engage with personally and academically challenging, triggering, and eye-opening material. Consequently, it becomes important to ask what is at stake in making use of this concept to create spaces to which marginalized subjects may turn to be heard and witnessed, to express defiance, or to be their authentic selves free from the strictures of traditional learning environments.

As Lauren Berlant (2001) notes, we have long been encouraged to seek out the safe spaces, those spaces "where there is no trouble." $\mathrm{But}$ this desire for spaces free from emotional pain or societal control is no less than a "foggy fantasy." Even still, we may not be so quick to discard the concept of "safe space," which, for many of us, may have served as a pedagogical security blanket in an otherwise violent world. Thus, even if we maintain an interest in creating such intentional spaces (even as we acknowledge their impossibility), it seems we cannot hope to construct environments in which there are no moments of discomfort, fear, contention, or stress. The queer studies classroom is not-cannot be-such a space "where there is no trouble." Instead, such learning requires, to paraphrase Donna Haraway, a "staying with the trouble." 
Building upon this tension, Audrey Thompson summarizes one of the key debates around safe spaces:

The solemnity with which teachers, students, and researchers invoke the ideal of a "safe space" suggests that there are literal pedagogical conditions under which students can be free from self-doubt, hostility, fear, or nonaffirmation. ... [But] what we count as "safe" is an imaginary construction reliant on ritualized forms of control. ... Safety from overt harm that is framed in terms of civility ... allows us [to] imagine a "normal" student and extend some of his needs to other students. (cited in Stengel and Weems 2010 , pp. 505-506 $)^{2}$

Indeed, an uncritical or unreflective use of safe spaces often suggests the (desired) absence of difficulty or debate. For example, we often avoid "difficult dialogues" around difference. As Gale Young (2003) writes, "This 'code of silence' is a reflection of a societal denial that cultural factors matter and that such things as sexism, racism, and White privilege exist. To avoid feeling awkward or making others uncomfortable, faculty often perpetuate the code of silence" (p. 349). Although it is our responsibility to address such silences, we often do not know how, with "safe space" being a convenient cover for not discussing certain topics.

Even as we reject the idea that the classroom could ever be fair, democratic, and devoid of power relations, we must interrogate our responsibility as queer educators to queer students, transgender and gender nonconforming students, and students of color. Because the world "out there" is indeed violent and unsafe, should we strive to create environments that are zones of acceptance and safety? As Melissa Redmond (2010) echoes, "in spite of racism, sexism, caste, ableism, heteronormativity, and other oppressive systems, can students and teachers construct 'intentional spaces' in which they engage to learn and un-learn their lives?" (pp. 8-9). For queer studies courses in particular, it is important to acknowledge that the process that many students undergo, in which their perspective may dramatically shift, often to a point of no return, is necessarily an uncomfortable - if not also contentious and stressful-experience. Megan Boler's "pedagogy of discomfort” (1999) remains a useful concept in that it encourages us to sit with our emotions and discomfort around discussing oppression and social injustice, including homophobia and racism, with the goal of creating social change and new ways of relating to one another. Boler (2000) elaborates elsewhere: "a discussion 
of racism or homophobia cannot rely simply on rational exchange, but must delve into the deeply emotional investments and associations that surround perceptions of difference and ideologies. One is potentially faced with allowing one's world-views to be shattered, in itself a profoundly emotionally charged experience" (p. 325).

Further, even as we may recognize a need for open spaces where students can think through challenging material and difficult emotions, we might also be skeptical of deploying a neoliberal rhetoric of "safety" and "security" that many of us as queer scholars and pedagogues want to dismantle. Indeed, we might wonder if encouraging safe spaces (or at least terming them so) is feeding into a neoliberal focus on safety and exclusionary practices. If we see neoliberalism for what it is-ideologies and policies that destroy resources created for vulnerable populations, redistribute wealth away from the poor and to the elite, strip away achievements made by social movements, and increase criminalization and immigration enforcement (Bassichis et al. 2011) - it is worth being wary of using a discourse of safety and security when we speak of creating intentional spaces free of violence and discrimination.

In her discussion of the gendered aspects of security and safety in neoliberal times, Inderpal Grewal (2006) states that the contemporary issue of security/insecurity pervading American politics forces us to think about feminisms "in newly urgent ways" (p. 25). Similarly, we might consider how the increased focus on secure spaces prompts timely reflections for queer theory and pedagogy. Grewal goes on to ask: "How do we understand what is happening with feminism when feminist discourses are used to bomb and to liberate, when feminist discourses, strategies, and injuries become available in new and unintended ways to empower, to secure, and to destroy?" (p. 25). And we might ask the same question of queer studies, particularly as we witness the ways in which homonationalist discourses have been taken up to bolster homeland security at the expense of other groups and nations who are constructed as backward, retrogressive, and homophobic. Even as it may claim that they are fluid and permeable, neoliberalism delineates the borders and boundaries of the public and the private, reifying divisions between insiders and outsiders, us and them. Who, then, is deemed worthy of safety and protection? And from whom? At whose expense does the security of some come?

Queer pedagogy aims to open up dialogue and resist essentializing notions while taking a long critical look at processes of normalization through which we are consistently constructed. We are forced to question 
the student/instructor relationship and to be critical of pedagogy itself. Bryson and de Castel's (1993) commentary on queer pedagogy and praxis further elucidates what we might hope for from a critically queer approach to teaching and learning:

Queer pedagogy could refer to the deliberate production of queer relations and to the production of subjectivities as deviant performance- that is to say, to a kind of postmodern carnivalesque pedagogy of the underworld, as agitation <implemented deliberately to interfere with, to intervene in the production of so-called normalcy in schooled subjectss .... It seems that a worthwhile avenue for the elucidation of a queer praxis might be to consider the value of an actively queerying pedagogy — of queering its technics and scribbling graffiti over its texts, of colouring outside the lines so as to deliberately take the wrong route on the way to school-going in an altogether different direction than that specified by a monologic destination. (pp. 298-299)

Following in this line of queer pedagogy, it is integral to discuss the dynamics of the classroom itself, that is, what the space becomes and what we all become within it. The question of who is allowed and encouraged to speak and who is being heard (and not heard) is also central to this discussion. While the concept of "student voice" and the idea of "helping" students speak has been shown to be problematic (Ellsworth 1989), listening - to ourselves and to one another-is, I believe, at the heart of a queer pedagogical approach. One of the pedagogical challenges encountered in disciplines like queer studies that attempt to question and subvert preconceptions about the world around us is that we inevitably approach the material with particular assumptions, beliefs, and values. And we all speak from a certain subject position that is an accumulation of our upbringing and our past and present experiences. It remains important for each of us-instructor included-to examine our own subject positions and how it structures our worldview. Pointing out the myriad social categories that we all inhabit and then together reflecting on how our own subjectivity is composed of various intersecting identifications, many of which carry with them certain invisible privileges that affect not only our daily lives but also our presence in the classroom, can be a strategy for encouraging open-minded speaking and listening. However, safe space may not be able to save us here, for queer studies and queer pedagogy are themselves "unsafe" projects in that they seek to upend norms, question authority, and dismantle identity categories. 
But perhaps it is through discarding illusions of safety that we may approach something closer to open dialogue that takes at its core respect, curiosity, and the possibility for growth. As Gloria Anzaldúa (2002) writes:

$[T]$ here are no safe spaces. "Home" can be unsafe and dangerous because it bears the likelihood of intimacy and thus thinner boundaries. Staying "home" and not venturing out from our own group comes from woundedness, and stagnates our growth. To bridge means loosening our borders, not closing off to others. Bridging is the work of opening the gate to the stranger, within and without. To step across the threshold is to be stripped of the illusion of safety because it moves us into unfamiliar territory and does not grant safe passage. To bridge is to attempt community, and for that we must risk being open to personal, political, and spiritual intimacy, to risk being wounded. (p. 3)

And it is in Anzaldúa's accurate admission that there are no safe spaces that I grow all the more hesitant to throw away the concept and the hope, for it is through stepping across the threshold and risking being wounded that we grow. Queer pedagogy calls us to critique the concept of "safe space" even as we strive toward an inclusivity and safety that will never actually exist. Because of what queer pedagogy does, it becomes an important method for simultaneously subverting the notion of "safe space" and holding onto it for dear life.

Susanne Luhmann (1998) forces us to think critically about our work as queer teachers and researchers:

If queer pedagogy $\ldots$ is foremost concerned with a radical practice of deconstructing normalcy, then it is obviously not confined to teaching as, for, or about queer subject(s). Moreover, the refusal of any normalization, be it racist, sexist, or whatever, necessarily has to be part of the queer agenda. ... [Q]ueer theory must persist in self-critiques and hence reflect on how normalization may also constitute lesbian and gay studies. (pp. 128-129)

This focus on self-critique must be key to our engagement with ambiguous and ambivalent concepts like "safe space." Just as engaging in metadiscursive practices that name and discuss the power relations, hierarchies, and processes we are bound up in may have a liberatory dimension, perhaps repeatedly critiquing the notion of "safe space" in the classroominvoking its impossibility because we are constructed by the world outside wherein our ancestral lineage and the existence of oppression, violence, 
white supremacy, homophobia, transphobia, xenophobia, ableism, racism, and ageism are passed to us-could get us to a safer space. Indeed, I echo Bryson and de Castel's call for embracing imperfection as we negotiate this quagmire of safety: "praxis makes im/perfect; that is to say, an eclectic melange of the wonderful, the awful, and the in-between. And perhaps, in pedagogical matters, im/perfect outcomes are necessarily the norm. Just as 'safe sex' has been discredited, there may ... be no such thing as a 'safe pedagogy.' But what about the notion of a 'safer' pedagogy?” (p. 300).

\section{Notes}

1. Although Berlant here refers to heterosexual intimacy, it is not so difficult to apply this notion to "other" sexualities, particularly at a time when gay rights discourses occupy the American newsreel.

2. Thompson extends her argument to more radical ideas of safe spaces, which may "attempt to recognize terms of safety referenced to the situations of oppressed and marginalized students" (cited in Stengel and Weems 2010, p. 506). But echoing Berlant, she states that even though "such spaces may feel safe, the safety is nevertheless imaginary insofar as it is framed by what we desire, resist, fear, and 'need.' ... [R] eimagining educative safety requires playing with and against our existing desires, fears, assumed needs" (Stengel and Weems 2010, p. 506).

\section{REFERENCES}

Anzaldúa, G. (2002). (Un)natural bridges, (un)safe spaces. In G. Anzaldúa \& A. Keating (Eds.), This bridge we call home: Radical visions for transformation (pp. 1-5). New York: Routledge.

Bassichis, M., Lee, A., \& Spade, D. (2011). Building an abolitionist trans and queer movement with everything we've got. In E. A. Stanley \& N. Smith (Eds.), Captive genders: Trans embodiment and the prison industrial complex (pp. 15-40). Oakland: AK Press.

Berlant, L. (2001). The subject of true feeling: Pain, privacy, and politics. In A. Sarat \& T. Kearns (Eds.), Cultural pluralism, identity politics, and the law (pp. 49-84). Ann Arbor: University of Michigan Press.

Boler, M. (1999). Feeling power: Emotions and education. New York: Routledge.

Boler, M. (2000). All speech is not free: The ethics of "affirmative action pedagogy". Philosophy of Education, 321-329.

Bryson, M., \& de Castel, S. (1993). Queer pedagogy: Praxis makes im/perfect. Canadian Journal of Education/Revue canadienne de l'éducation, 18(3), 285-305. 
Ellsworth, E. (1989). Why doesn't this feel empowering? Working through the repressive myths of critical pedagogy. Harvard Educational Review, 59(3), 297-324.

Grewal, I. (2006). "Security Moms" in the early twentieth-century United States: The gender of security in neoliberalism. WSQ: Women's Studies Quarterly, $34(1 \& 2), 25-39$.

Henry, A. (1994). There are no safe places: Pedagogy as powerful and dangerous terrain. Action in Teacher Education, 15(4), 1-4.

Luhmann, S. (1998). Queering/querying pedagogy? Or, pedagogy is a pretty queer thing. In W. F. Pinar (Ed.), Queer theory in education (pp. 120-132). New York: Routledge.

Redmond, M. (2010). Safe space oddity: Revisiting critical pedagogy. Journal of Teaching in Social Work, 30, 1-14.

Stengel, B. S., \& Weems, L. (2010). Questioning safe space: An introduction. Studies in Philosophy and Education, 29, 505-507.

Young, G. (2003). Dealing with difficult classroom dialogue. In P. Bronstein \& K. Quina (Eds.), Teaching gender and multicultural awareness (pp. 347-360). Washington, DC: American Psychological Association. 